\title{
Organic Coriander Production: A Review
}

\author{
Lal G*, Shiv Lal, Choudhary MK and Chaudhary N \\ ICAR - National Research Centre on Seed Spices, India
}

*Corresponding author: Lal G, ICAR - National Research Centre on Seed Spices, Tabiji-305 206, Ajmer, India

\begin{abstract}
India is considered as "Bowl of Spices" from prehistoric period. Coriander is an annual seed spice crop, which belongs to family Apiaceae. It is native of Mediterranean region. The aromatic characters of plants are due to presence of linalool compound in essential oil of seeds. The green leaves of coriander are used in salads and are a good source of vitamin A and vitamin C. Major active constituents of coriander essential oils and fatty oil. The essential oil content of the weight of ripe and a dried fruit of coriander varies between 0.03 and $2.6 \%$ and the content of fatty oil varies between 9.9 and $27.7 \%$. Coriander leave showed stronger antioxidant activity than the seeds. It lowered the blood sugar when added to the diet of diabetic patients. The anti-hyperglycemic action of coriander is associated with stimulation of insulin secretion and enhancement of glucose uptake and metabolism by muscle, reflecting the effects of more than one active constituent. Corianders are generally grown in less fertile soil and are needed less input (fertilizers and other chemical). In this context, organic farming could be great opportunity in the production of safe and quality coriander as it is ease to shift towards certified organic farming. This review paper attempts to bring scope and importance of organic production of coriander a seed spices crop.
\end{abstract}

Keywords: Coriander; Organic system; plant growth; yield

\section{Introduction}

Coriander is one of the most important spice cultures in the world, known as Coriandrum sativum Linn. It is an annual herb derived from the Greek word "koris" which means "bad bug" because of the unpleasant smell of green and immature fruits. Green leaves are used in chutneys, sauces, curry and other preparations because of its pleasant aroma, the aroma of dishes and the seasoning of curry and soups. Coriander is grown for commercial purposes in India, Morocco, Russia, Hungary, Poland, Romania, Bulgaria, Guatemala, Mexico and the United States. In India, it is mainly grown in Rajasthan, Madhya Pradesh, Gujarat, Tamil Nadu and Andhra Pradesh. At the moment, humans are more concerned about your health problems and traveling to protect all foods. Demand for organic products is very high in the domestic and international markets as they are free of insecticides, pesticides and other residues of harmful chemicals. So this production system is human and environmentally friendly. The minimization of various health risks, insecticide pollution, and insect resistance to insecticides, the spread of pests and their re-emergence are urgently needed. The demand for coriander seeds and other organic products is increasing in these regions due to the high purchasing power and the considerable presence of health-conscious consumers. Organic food consumption in India is very low compared to Western markets. The organic food market in India is extremely disorganized and fragmented, offering tremendous growth opportunities for domestic and international players. India exports mainly processed organic food products, organic rice, beverages and other grains and millets to the United States, Canada, Europe and Southeast Asian countries. India is the $10^{\text {th }}$ largest country in the world in terms of organic certification. The productivity of coriander is influenced by several factors such as soil, varieties, fertilizer management and various agricultural techniques used for cultivation. Nutrients play a vital role in the functioning of normal physiological processes during the period of growth and development of plants. However, to achieve a higher economic return, a balanced intake of nutrients is one of the key factors [1]. Organic sources are directly or indirectly useful for increasing the availability and uptake of soil nutrients and, ultimately, for increasing the yield and quality of coriander without mitigating the adverse effects on the physicochemical properties of the soil. 
Organic coriander production is holistic and improves the health of the ecosystem, including biodiversity, life cycles and soil biological activity. It emphasizes the use of management practices rather than the use of non-agricultural inputs, taking into account that regional conditions require a locally adapted system. India is endowed with various types of organic nutrients naturally available in different parts of the country, which will greatly facilitate the biological cultivation of crops. The main benefits of organic coriander production are that organic coriander is highly profitable due to export demand and that organic products are of high quality, safe, nutritious and environmentally friendly. The associated benefits are the protection of long-term soil fertility, based on the principle of sustainable agriculture, which allows the use of insoluble nutrient sources through micro-organisms [2,3].

\section{Botanical Description}

Coriander ( $\mathrm{L}$ ) is an annual herb. It is one of the first seed spice to be used by mankind. Coriander (which belongs to the family Apiaceae (Umbelliferae) is mainly cultivated from its seeds throughout the year [4]. Its leaves are small herb having many branches and sub-branches. New leaves are oval but aerial leaves are elongated. Flowers are white, having slightly brinjal like shades while fruit are round in shape [2]. Macroscopic characteristic of fruit is globular, mericarps usually united by their margins forming a cremocarp about 2-4 mm in diameter, uniformly brownish-yellow or brown, glabrous, sometimes crowned by then remains of sepals and styles, primary ridges 10 , wavy and slightly inconspicuous secondary ridges 8 , straight, it has aromatic odour. It has spicy and characteristic taste $[2,5]$.

\section{Research Activities in Organic Coriander Produc- tion}

Research activities are being undertaken to bridge the yield gap of organic farming in comparison to modern farming. Salient achievements of research work are summarized herewith. The organic sources of nutrient influence positively all the growth and yield attributes [6]. reported that among the treatments (20 t FYM ha $^{-1}, 5$ t vermicompost $t$ ha $^{-1}$ and $2 \mathrm{t}$ biomeal ha ${ }^{-1}$ ),the treatment 20 t FYM ha ${ }^{-1}$ recorded the maximum plant height, primary branches, secondary branches, number of leaves, east-west spread and southnorth spread in coriander. Similarly that the organic manures (FYM 20 tonnes per ha) recorded maximum plant height, number of leaves per plant, number of umbels per plant, number of umbellates per umbel, number of seeds per umbellate, number of seeds per plant, seed yield per plant, seed yield per plot, seed yield per hectare, test weight and germination per cent in coriander crop [7]. The effects of different quantities of vermicompost on yield and yield components of coriander evaluated by [8]. Vermicompost treatments were consisting $0,25,50$ and $75 \%$ of pot volume. Results showed that application of vermicompost increased all evaluated traits that in regard to biologic yield, 1000 seeds weight, seed yield, plant height, percent and yield of essential oil and oil had significant difference with control. Based on these results, vermicompost had the least influence on shoot number in plant, harvest index and bearing rate. Likewise [9] Plant growth promoter bacteria also showed significant effects on umbels/plant and seed yield (except 1000 seed weight). The maximum umbels/plant was obtained with two treatments of inoculation with Azotobacter and inoculation with Azospirillum and seed yield were obtained with Azospirillum inoculation. Interactions between factors on umbels/ plant and 1000 seed weight were significant. Differences between control and other treatments were significant, as umbels/plant in treatment of 15 ton/ha cattle manure application and inoculation together and also, 1000 seed weight and seed yield in treatment of 20 ton/ha cattle manure application and inoculation with Azospirillum were higher than control.

The application of different organic modules to the coriander crop influenced significantly the seed yield per ha. The maximum seed yield (1546.66 kg ha-1) was recorded in Module-1 (Vermicompost (5t/ha), foliar spray of garlic extract (5\% @ $2 \mathrm{~kg}$ $\left.\mathrm{ha}^{-1}\right)+$ neem oil (2\% @ 5 liter ha ${ }^{-1}$ ) as against to the minimum seed yield (1288.33 $\mathrm{kg} \mathrm{ha}^{-1}$ ) recorded under Module-2 (FYM (10 t/ ha' $\left.{ }^{1}\right)$, foliar spray of garlic extract(5\% @ $2 \mathrm{~kg} \mathrm{ha}^{-1}$ ) alone). Similarly, under interaction effects, it was recorded that $\mathrm{Mx} \mathrm{V}$ interaction had no significant effect on coriander [10]. The application of different organic modules influenced significantly the essential oil content of coriander grains [10]. The maximum essential oil content $(0.41$ $\mathrm{g} \mathrm{kg}^{-1}$ ) was recorded in coriander produced with the application of organic Module-1(Vermicompost (5t/ha), foliar spray of garlic extract 5\%@2 kg ha-1) + neem oil 2\% @ 5 liter ha-1) as against with Module-2 (FYM (10 t/ ha $\mathrm{h}^{-1}$ ), foliar spray of garlic extract $5 \%$ @ $2 \mathrm{~kg} \mathrm{ha}^{-1}$ ) alone). Vermicompost + nitroxin and barvar-2 had the highest stimulatory effect on phosphorus amount and nitrox in increased the nitrogen content in coriander [11]. Reported that the vermicompost had significant effects on various chemical traits except linalool percent in essential oil, as the highest essential oil content, essential oil yield and alpha pinene percent in essential oil were obtained after applying 6 ton/ha vermicompost. The minimum cymene percent in essential oil were obtained after applying 6 ton/ ha vermicompost. Biofertilizer also showed significant effects on essential oil yield only [12]. The highest yield attributes and yield of coriander and cumin was recorded with insect pest control by spray of Sulphur compound of karanj extract-1\% which is at par with application of Allylisothio cynate- 1 percent and application of neemoil-2 percent [13]. The organic module (Vermicompost $5 t /$ ha + Sheep manure (10 t/ha) +Azotobacter $(100 \mathrm{ml} / \mathrm{kg}$ seed $)+\mathrm{PSB}$ $(100 \mathrm{ml} / \mathrm{kg} \mathrm{seed})+\mathrm{ST}(10 \mathrm{~g} / \mathrm{kg}$ seed $)+\mathrm{SA}$ of Trichoderma $(2.5 \mathrm{~kg} /$ ha)+soil application of neem cake $(150 \mathrm{~kg} / \mathrm{ha})+$ foliar spray of onion /garlic extract (5\%) $2 \mathrm{~kg} / \mathrm{ha}+$ foliar spray of neem oil (2\%) 5litre/ha gave maximum seed yield $(1520 \mathrm{~kg} / \mathrm{ha})$ with high growth and yield parameters of coriander. Therefore, application of various organic sources of nutrition along with organic way of disease and insect pest management recommended for realizing higher growth, yield attributes and yield of coriander. $\mathrm{ACr}^{-1}$ variety 
of coriander performed better over RCr-41, which exhibited higher vegetative growth i.e. plant height at 30 days $(4.23 \mathrm{~cm}), 60$ days $(11.07 \mathrm{~cm}), 90$ days $(91.19 \mathrm{~cm})$ and at harvest $(99.08 \mathrm{~cm})$, and primary branches (8.08), as well as yield attributes viz. umbel/ plant (16.92), umbellate/umbel (4.90) and seed/umbellate (10.21) and yield (1405.35 kg/ha). Thus, it is inferred that application of organic module along with improved variety $\mathrm{ACr}-1$ is better for realizing high yield of coriander [13].

The number of umbels/plant and number of umbelets/umbel of coriander were influenced significantly due to various organic treatments. The maximum number of umbels/plant (61.90) and umbelets/plant (7.11) was counted with $\mathrm{T}_{4}$ (Application of FYM $25 \%\left(2.5 \mathrm{t} \mathrm{ha}^{-1}\right)+$ Vermi-compost $75 \%$ (3.75 $\left.\mathrm{t} \mathrm{ha}^{-1}\right)$ treatment. Number of seeds/ umbel, weight of 1000 seeds and the seed yield of coriander influenced significantly due to various organic treatments. However, the maximum values i.e. $60.53,11.32 \mathrm{~g}$ and $14.58 \mathrm{q} /$ ha were achieved due to application of FYM $25 \%$ (2.5 t ha$\left.{ }^{1}\right)$ + vermi-compost $75 \%$ (3.75 $\left.\mathrm{t} \mathrm{ha}^{-1}\right)$ treatment. The progressive increase in yield contributing parameters might be attributed to increase in growth parameters application of FYM $25 \%\left(2.5 \mathrm{t} \mathrm{ha}^{-1}\right)$ + vermi-compost $75 \%$ (3.75 $\mathrm{tha}^{-1}$ ) due to balance nutrition, which might have resulted in accelerating the photosynthetic activities and improved the sink, however, the higher yield was only due to increase in yield attributing traits viz. number of umbels per plant, number of umbelets/umbel, number of seeds/umbel and 1000 seeds weight [14]. The essential oil as well as moisture content in the seed of coriander varied significantly with the application of various organic sources of nutrients either alone or in combination. Incorporation of FYM $25 \%$ (2.5 $\left.\mathrm{t} \mathrm{ha}^{-1}\right)$ in combination with Vermicompost $75 \%$ (3.75 $\mathrm{t} \mathrm{ha}^{-1}$ ) recorded maximum essential oil and moisture contents of 0.66 and 12.7 per cent, respectively. Minimum values in both the parameters were obtained with control treatment. The progressive improvement in moisture content of coriander seed with the use of various components of organic sources might be due to the increase in growth parameters, which might have resulted in improved uptake of nutrients and photosynthetic activities and finally the quality parameters of coriander through the process of enzymatic activities stimulated by plant growth component [14]. The aphid infestation on coriander crop was managed by application of neem based commercial formulation like Neemarin at $1 \%$ and seed extract of neem (Azadirachata indica), karanj (Pongamia sp.), buken (Melia sp.) and pride of India (Lagerstroemia indica) reduce the aphids population by 50 per cent within 7 days of application [15]. The organic nutrients could also enhance the vegetative growth and yield of coriander crop [13]. The coriander varieties performed significantly under organic system uniformly. Among the total varieties, Azad dhaniya-1 showed significant influence on plant growth parameters and yield attributes recorded highest seed yield (1246.6 kg/ha) followed by ACr-1(1225.20 kg/ha). It may also be due to the varietal influence but it clearly indicate that coriander varieties suitable for organic farming [16-19].

\section{Conclusion}

Literatures reviewed have been shown that organic farming could be able to produce quality and safe coriander seed as spices. Nutrition requirement and pest-disease management of organically have been worked out in many coriander crops. Suitability of varieties under organic farming system to address the low yield issue is being also undertaken. Disagreements about the profitability and low yield in organic farming are acute, but there is a strong consensus on its eco-friendly nature and inherent ability to protect human health. Low yield issues is minimize through proper and timely nutrient, pest and disease management. Yield loss in organic farming can be compensated by converting farm to organic through different government bodies through the (All India Network Programmed on Organic Farming) and others. Approved organic produce are fetching premium price in the market, so that profitability of organic farming can be recouped to some extent.

\section{References}

1. Singh K (1976) Manorial Requirement of Vegetable Crops. ICAR, New Delhi, India.

2. Handa SS and Kaul MK (1996) Supplement to cultivation and utilization of medicinal plant, National Institute of science communication, Regional research laboratory (CSIR), Jammu-Tavi, India. pp. 818.

3. FAO (1999) Organic Agriculture, Food and Agriculture Organization of the United Nations, Rome.

4. Mhemdi H, Rodier E, Kechaou N, Fages J (2011) A supercritical tunable process for the selective extraction of fats and essential oil from coriander seeds. J Food Engg 105(4): 609-616.

5. Mhemdi H, Rodier E, Kechaou N, Fages J (2011) A supercritical tunable process for the selective extraction of fats and essential oil from coriander seeds. J Food Engg 105(4): 609-616.

6. Vasmate SD, Kalalbandi BM, Patil RF, Digrase SS, Manolikar RR (2007) Effect of spacings and organic manures on growth of coriander. Asian J Hort 2(2): 266-268.

7. Vasmate SD, Kalalbandi BM, Patil RF, Digrase SS, Manolikar RR (2008) Effect of spacing and organic manures on seed of coriander (Coriandrum sativum L). Asian J Hort 3(1): 127-129.

8. Moslemi M, Aboutalebi A, Hasanzade H, Farahi MH (2012) Evaluation the effects of different levels of vermicompost on yield and yield components of Coriander (Coriandrum sativum L). Annals of Biological Research 3(10): 4852-4853.

9. Darzi MT (2012) Effects of organic manure and biofertilizer application on flowering and some yield traits of coriander (Coriandrum sativum $L$ ). International Journal of Agriculture and Crop Sciences (IJACS) 4(3): 103107.

10. Lal G, Vashisth T, Mehta RS and Ali SF (2012) Studies on different organic modules for yield and quality of coriander (Coriandrum sativum L). International J Seed Spices 2(1): 1-6.

11.Jahanshahi S, Zadehbagheri M, Aboutalebi A (2013) Effect of vermi compost, azotobacter and barvar ii on some quantitative and qualitative traits of coriander (Coriandrum sativum L) medicinal plant. Journal of crop production research (environmental stresses in plant sciences) 4(4): 391-400.

12. Darzi MT (2015) Effects of organic fertilizer and azotobacter and azospirillum bacteria on concentration and composition of essential 
oil of Coriander (Coriandrum Sativum L). International Journal of Agricultural and Biosystems Engineering 9(8): 1.

13. Annual report (2012-13 \& 2017-18) ICAR-National Research Centre on Seed Spices Tabiji, Rajasthan, India.

14. Kumar R, Singh MK, Kumar V, Verma RK, Kushwah JK, et al. (2015) Effect of nutrient supplementation through organic sources on growth, yield and quality of coriander (Coriandrum sativum L). Indian J Agric Res 49(3): 278-281.

15. Kant K, Meena NK, Meena SR (2016) Important insect pests of seed spices and their management. Sustainable Production of seed spices under changing climate scenario. NRCSS, Ajmer, Rajasthan, India, p. 8184.
16. Lal G, Harisha CB, Meena NK, Meena RD, Choudhary MK (2017) Performance of coriander varieties (Coriandrum sativum $L$ ) under organic management system. International J Seed Spices 7(1): 8-11.

17. Lal G, Chaudhary N, Lal S, Choudhary MK (2019) Production of seed spices organically: A review Annals of Horticulture 12(1): 11-19.

18. Lal G, Singh R (2016) Comprehensive evaluation of coriander (Coriandrum sativum $L$ ) varieties under different organic modules. Indian Journal of Agricultural Sciences 86: 31-36.

19. Momin Abidhusen H, Acharya Sawapnil S and Gajjar V Amit (2012) Coriandrum sativum- Review of advances in phytopharmacology. IJPSR 3(5): 1233-1239.

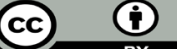

This work is licensed under Creative Commons Attribution 4.0 License

To Submit Your Article Click Here: Submit Article

$\begin{gathered}\text { Current Investigations in Agriculture } \\ \text { and Current Research }\end{gathered}$
Assets of Publishing with us
- Global archiving of articles
- Immediate, unrestricted online access
- Rigorous Peer Review Process
- Authors Retain Copyrights
- Unique DoI for all articles

